\title{
Stratigraphic Framework and Depositional Sequences in the Lower Silurian Regional Oil and Gas Accumulation, Appalachian Basin From Jackson County, Ohio, Through Northwestern Pennsylvania, to Orleans County, New York
}

By Robert T. Ryder

Chapter E.3.3 of

Coal and Petroleum Resources in the Appalachian Basin:

Distribution, Geologic Framework, and Geochemical Character

Edited by Leslie F. Ruppert and Robert T. Ryder

Professional Paper 1708 
Suggested citation:

Ryder, R.T., 2014, Stratigraphic framework and depositional sequences in the Lower Silurian regional oil and gas accumulation, Appalachian basin from Jackson County, Ohio, through northwestern Pennsylvania, to Orleans County, New York, chap. E.3.3 of Ruppert, L.F., and Ryder, R.T., eds., Coal and petroleum resources in the Appalachian basin; Distribution, geologic framework, and geochemical character: U.S. Geological Survey Professional Paper 1708, 1 p., 8-p. pamphlet, 2 oversized sheets, http://dx.doi.org/10.3133/pp1708E.3.3. [This chapter is a re-release of U.S. Geological Survey Geologic Investigations Series Map I-2726, by Robert T. Ryder, 2000; available at http://pubs.usgs.gov/ imap/i-2726/.] 


\title{
Stratigraphic Framework and Depositional Sequences in the Lower Silurian Regional Oil and Gas Accumulation, Appalachian Basin From Jackson County, Ohio, Through Northwestern Pennsylvania, to Orleans County, New York
}

\author{
By Robert T. Ryder ${ }^{1}$
}

This chapter is a re-release of U.S. Geological Survey Geologic Investigations Series

Map I-2726, of the same title, by Ryder (2000).

To access sheet 1 , click here.

To access sheet 2 , click here.

To access the accompanying text for the report, click here.

\section{Reference Cited}

Ryder, R.T., 2000, Stratigraphic framework and depositional sequences in the Lower Silurian regional oil and gas accumulation, Appalachian basin; From Jackson County, Ohio, through northwestern Pennsylvania, to Orleans County, New York: U.S. Geological Survey Geologic Investigations Series Map I-2726, 8-p. pamphlet, 2 sheets. (Also available at http://pubs.usgs. gov/imap/i-2726/.) 